\title{
Analysis of the Component and Immunological Efficacy of Chamaecyparis obtusa Leaf Extract
}

\author{
Joung Hee $\mathrm{Kim}^{1}$, Syng-Ook Lee ${ }^{2}$, Kook Bae Do ${ }^{3}$, Won Dae Ji ${ }^{3}$, Sun Gun Kim ${ }^{4}$, Young Doo Back ${ }^{5}$, \\ Keuk-Jun Kim ${ }^{1}$ \\ ${ }^{1}$ Department of Biomedical Laboratory Science, Daekyeung University, Gyeongsan, Korea \\ ${ }^{2}$ Department of Food Science and Technology, Keimyung University, Daegu, Korea \\ ${ }^{3}$ Mediway Korea Co., Ltd., Gyeongsan, Korea \\ ${ }^{4}$ Traditional Korean Medicine Technology Division R\&D Department Herbal Medicine Team, Gyeongsan, Gyeongbuk, Korea \\ 5 Department of Clinical Pathology, Daegu Health College, Daegu, Korea
}

\section{편백나무 잎 추출물의 성분분석과 면역효능에 관한 연구}

\author{
김정희 ${ }^{1}$, 이승욱 ${ }^{2}$, 도국배 ${ }^{3}$, 지원대 ${ }^{3}$, 김선건 $^{4}$, 백영두 $^{5}$, 김극준 $^{1}$ \\ ${ }^{1}$ 대경대학교 임상병리과, ${ }^{2}$ 계명대학교 자연과학대학 식품가공학전공, ${ }^{3}$ (주메디웨이코리아, ${ }^{4}$ 한약진흥재단 천연물 의학팀, ${ }^{5}$ 대구보건대학교 임상병리과
}

\begin{abstract}
Chamaecyparis obtusa (CO) has recently been attracting attention because of its beneficial effects on skin allergies, atopic dermatitis, and skin diseases, such as acne and eczema. In the present study, the extract from CO leaf grown in Jangseong gun, Jeollanam-do, Korea was evaluated for its anti-oxidant, anti-inflammatory, and anti-allergic effects in vitro. The total polyphenol content of the CO leaf extract was $25.89 \pm 0.31 \mathrm{mg}$ gallic acid equivalents (GAE)/g. Gas-chromatography mass-spectrometry (GC-MS) analysis revealed the presence of six compounds in the CO leaf extract: $\alpha$-terpinene (3.03 mg/g), $\alpha$-terpineol $(9.48 \mathrm{mg} / \mathrm{g}$ ), limonene $(5.96 \mathrm{mg} / \mathrm{g})$, borneol $(59.78$ $\mathrm{mg} / \mathrm{g})$, myrcene $(4.85 \mathrm{mg} / \mathrm{g})$, and sabinene $(11.31 \mathrm{mg} / \mathrm{g})$. The $\mathrm{RC} \mathrm{C}_{50}$ values of the CO leaf extract for $\mathrm{H}_{2} \mathrm{O}_{2}$ and $\mathrm{ABTS}$ radical were $5.47 \pm 0.13 \mathrm{mg} / \mathrm{mL}$ and $4.00 \pm 0.01 \mathrm{mg} / \mathrm{mL}$, respectively. In addition, the $\mathrm{CO}$ leaf extract showed significant inhibitory effects on lipopolysaccharide-induced nitric oxide production in RAW 264.7 cells and IgE-induced release of $\beta$-hexosaminidase (degranulation) in mast-cell like RBL-2H3 cells. The cell viability assay showed that the CO leaf extract (100 800 $\mu \mathrm{g} / \mathrm{mL}$ ) did not affect the viability of human normal skin fibroblast CCD-986sk cells significantly. Overall, these results suggest that the CO leaf extract is a potential functional cosmetic ingredient that can exert anti-oxidant, anti-inflammatory, and anti-allergic effects.
\end{abstract}

Key words: Anti-inflammation, Anti-allergy, Anti-oxidant, Chamaecyparis obtusa

This is an Open Access article distributed under the terms of the Creative Commons Attribution Non-Commercial License (http://creativecommons.org/licenses/by-nc/4.0) which permits unrestricted non-commercial use, distribution, and reproduction in any medium, provided the original work is properly cited.

Copyright ( 2018 The Korean Society for Clinical Laboratory Science. All rights reserved.
Corresponding author: Keuk-Jun Kim Department of Biomedical Laboratory Science, Daekyeung University, 65 Danbuk 1-gil, Jain-myeon, Gyeongsan 38547, Korea Tel: 82-53-850-1266

Fax: 82-53-850-1496 E-mail: biomed@tk.ac.kr

Received: December 7, 2017 Revised 1 ${ }^{\text {st: }}$ December 28, 2017 Revised 2 ${ }^{\text {nd }}$ : January 6, 2018 Revised $3^{\text {rd: }}$ January 16, 2018 Accepted: January 23, 2018

\section{서 론}

편백(Chamaecyparis obtusa, CO)은 히노끼(hinoki)나무 로 일반적으로 알려져 있고, 측백나무과(Cupressaceae) 편백 속(Charmaecyparis)에 속하며 중국, 일본, 한국에서 자란다 [1]. 편백나무 목재는 욕조, 가구 및 베개 충전재 제조, 오일 공급
원으로 사용되고 있으며, 편백나무 잎 추출물은 다양한 생물학 적 활성이 있어 의학의 자연적 근원으로 여겨왔으며 요로감염 의 치료효과와 강력한 항균활성 및 항염활성 등이 보고되었다 [2-5]. 또한 최근 편백나무에서 추출한 bioflavonoid의 경우 신 경보호 작용이 있다고 보고되었으며[6], monoterpenoids, sesquiterpenoids, flavonoids와 bioflavonoids 등은 편백나 
무 잎에서 추출한 다양한 종류의 생물학적 활성물질로도 잘 알 려져 있다[7-9]. 그러나 국내 전라남도 장성 지역 편백나무 잎 추출물의 항염 및 항알레르기 효과에 대해서는 보고된 바가 없 다. Haratake 등[10]은 피부 민감화의 경우 피부장벽 손상으로 표면 수분 함량이 감소되어 각질층의 유연성이 상실된 다고 보 고하였으며, Kim 등[11]에 따르면 피부 보호막의 기능 저하는 자극성 및 유해성 물질의 피부 침투가 용이해지고 반복되는 자 극 누적으로 인해 표피 기능과 구조의 변화를 일으켜 민감성 피 부가 된다고 한다. 피부장벽 기능의 손상은 또한 알레르겐의 피 부투과성을 높여서 피부염증을 악화시키는 여건을 만들게 되고 면역학적 기전에 의하여 발생한 피부의 염증 반응은 피부장벽 의 손상을 악화시킬 수 있는 것으로 알려져 있다[12]. 한편 피부 민감화 과정의 가장 큰 원인은 ceramide의 감소이며 이를 통해 표피 각칠층의 건조가 유도되는 것으로 보고되었으며[13], 외 용적 도포를 통한 ceramide 공급은 표피 수분의 함량을 높이고 각질층 정상화에 영향을 미쳐 민감성 피부를 개선하는 것으로 보고되었다[14].

본 연구는 장성 지역 편백나무 잎 추출물의 성분분석 및 생리 활성 탐색을 통해 향후 기능성 화장품, 연고 등의 산업화에 적용 가능성이 있음을 알아보고자 진행하였다.

\section{재료 및 방법}

\section{1. 추출}

본 연구에 사용된 편백나무 잎 추출물(C\&B Cosmetic, Choongnam, Korea)는장성지역의 편백나무 잎(Chamaecyparis obtusa Leaf) $20 \mathrm{~kg}$ 과 정제수 $80 \mathrm{~kg}$ 을 혼합교반, 밀봉상태 $105^{\circ} \mathrm{C}$ 에서 20 분간 처리, 멸균하여 진공상태 $60^{\circ} \mathrm{C}$ 에서 72 시간 가온하여 추출 및 응축수 처리하여 제균 여과 $(0.2 \mu \mathrm{M})$ 후 냉장보 관 사용하였다. 시판되는 원액으로 구입한 편백나무 잎 추출물 은 $50^{\circ} \mathrm{C}$ 에서 감압 건조하여 사용하였다.

\section{GC-MS (gas chromatography-mass spectrometry)를 이용한 편백나무 잎 추출물의 성분 분석}

성분분석은 Bose 등[9]의 크로마토그래피 방법을 이용하여 Shimadzu사의 GCMS-QP2010 Plus 시리즈 GC-MS (Shimadzu, Corp., Kyoto, Japan)로 분석하였다. 분석 컬럼은 길이 $30 \mathrm{~m}$, 내경 $0.25 \mathrm{~mm}$, 필름 두께 $0.25 \mu \mathrm{m}$ 을 사용하였으며, 이동상 가 스는 헬륨, 유속은 $2.0 \mathrm{~mL} / \mathrm{min}$, 시료량은 비분할 주입법으로 8 $\mu \mathrm{L}$ 을 주입하였으며, 주입구 온도는 $280^{\circ} \mathrm{C}$ 조건으로 진행하였 다. 오븐 온도는 승온 조건으로 $60^{\circ} \mathrm{C}$ 에서 1 분간 유지 후 $10^{\circ} \mathrm{C} / \mathrm{min}$ 으로 $100^{\circ} \mathrm{C}$ 까지 증가시킨 후 다시 $7.5^{\circ} \mathrm{C} / \mathrm{min}$ 으로 $250^{\circ} \mathrm{C}$ 로 승온하고 3 분간 유지한 후 $60^{\circ} \mathrm{C} / \mathrm{min}$ 으로 $280^{\circ} \mathrm{C}$ 까지 승온하여 1.5 분간 유지하였다.

\section{3. 총폴리페놀 함량}

총폴리페놀 함량 분석방법으로 널리 사용되고 있는 Folin-Denis법[15]을 응용하여 측정하였다. 즉 적절히 희석한 각 추출물 시료 용액에 2배로 희석한 Folin 시약을 동량 첨가하 고 잘 혼합하여 3 분간 방치한 후 시료와 동량의 $10 \% \mathrm{Na}_{2} \mathrm{CO}_{3}$ 를 서서히 가하였다. 이 혼합액을 1 시간 동안 방치한 후 UV/visible spectrophotometer (UVIKON 922, Kontron, Augsburg, Germany)를 사용하여 $700 \mathrm{~nm}$ 에서 흡광도를 측정하였다. 이 때 총폴리페놀 함량은 gallic acid를 이용하여 작성한 표준곡선 으로부터 구하여 gallic acid equivalents (mg TAE/g extract) 로 나타내었다.

\section{ABTS radical cation 소거작용 측정 2,2'-Azino-bis (3-ethylbenzothiazoline-6-sulfonic acid (ABTS)) 라디칼 소거 활성}

$\mathrm{ABTS}$ 라디칼 소거 활성은 $\mathrm{ABTS}^{+*}$ cation decolorization assay 방법[16]에 따라 시행하였다. $7 \mathrm{mM} \mathrm{ABTS}$ 와 $2.45 \mathrm{mM}$ potassium persulfate를 최종 농도로 혼합하여 실온 암소에서 24 시간 동안 방치하여 $\mathrm{ABTS}^{+}$을 형성시킨 후 $732 \mathrm{~nm}$ 에서 흡 광도 값이 $0.70( \pm 0.02)$ 이 되게 phosphate buffer saline (PBS, pH 7.4)으로 희석하였다. 희석된 용액 $990 \mu \mathrm{L}$ 에 추출물 $10 \mu \mathrm{L}$ 를 가하여 정확히 1 분 동안 방치한 후 $734 \mathrm{~nm}$ 에서 흡광도 를 측정하였다. 각 시료 추출물의 라디칼 소거 활성은 시료를 첨 가하지 않은 대조군의 흡광도를 $1 / 2$ 로 환원시키는 데 필요한 시 료의 농도인 $\mathrm{RC}_{50}$ 값으로 나타내었다. 이때 활성 비교를 위하여 trolox를 사용하였다.

\section{Hydrogen peroxide $\left(\mathrm{H}_{2} \mathrm{O}_{2}\right)$ 소거 활성 측정}

Lee 등[17]의 방법에 따라 96 well micro plate에 PBS 100 $\mu \mathrm{L}$ 와 물에 녹인 시료 $20 \mu \mathrm{L}$ 를 넣고 $1 \mathrm{mM} \mathrm{H}_{2} \mathrm{O}_{2}$ 를 가하여 5 분 방치한 다음, $1.25 \mathrm{mM} \mathrm{ABTS} 30 \mu \mathrm{L}$ 와 $\mathrm{PBS}$ 에 녹인 $1 \mathrm{U} / \mathrm{mL}$ peroxidase $30 \mu \mathrm{L}$ 를 첨가하여 $37^{\circ} \mathrm{C}$ 에서 10 분간 반응시킨 후 $405 \mathrm{~nm}$ 에서 흡광도를 측정하였다. 이때 활성비교를 위하여 ascorbic acid를 사용하였다.

\section{Nitric oxide (NO) 생성량 측정}

$\mathrm{RAW} 264.7$ 세포로부터 생성되는 활성질소 종인 nitric 
oxide (NO)의 양은 Green 등[18]의 방법을 이용하여 세포 배 양액 중에 존재하는 $\mathrm{NO}_{2}{ }^{-}$형태를 griess reagent와 반응시켜 측정하였다. RAW 264.7 세포를 DMEM 배지에 $1 \times 10^{5}$ cells/mL 농도로 96 well plate에 분주한 후 시료를 농도별로 처리하여 24시간 배양하였으며 lipopolysaccharide (LPS) $100 \mathrm{ng} / \mathrm{mL}$ 를 첨가하여 다시 24시간 배양시켰다. 세포배양 상 등액 $100 \mu \mathrm{L}$ 와 griess시약 $(1 \%$ sulfanilamide, $0.1 \%$ naphthylethylenediamine in $25 \%$ phosphoric acid) $100 \mu \mathrm{L}$ 를 혼합하 여 96 well plates에서 10 분간 반응시킨 후 biotek microplate spectrophotometer를 이용하여 $540 \mathrm{~nm}$ 에서 흡광도를 측정 하였다. $\mathrm{NO}_{2}{ }^{-}$표준곡선은 $\mathrm{NaNO}_{2}$ 를 농도별로 조제하여 사용 하였다.

\section{7. 비만세포의 탈과립( $\beta$-hexosaminidase) 측정}

RBL-2H3 세포는 10\% FBS와 1\% antibiotics (penicil$\mathrm{lin} / \mathrm{streptomycin)}$ 를 포함하는 DMEM 배지를 사용하여 $37^{\circ} \mathrm{C}$, $5 \% \mathrm{CO}_{2}$ incubator에서 배양하였다. 24 well-plate에 $2 \times 10^{5}$ cells/well로 세포를 분주하고 3시간 후 $1 \mu \mathrm{g} / \mathrm{mL}$ 의 DNP-specific IgE (Sigma-Aldrich, St. Louis, MO, USA)로 18시간 동안 감작 시키고 PBS로 4회 세척하였다. 이후 incubation buffer (119 $\mathrm{mM} \mathrm{NaCl}, 5 \mathrm{mM} \mathrm{KCl}, 0.4 \mathrm{mM} \mathrm{MgCl}_{2}, 20 \mathrm{mM} \mathrm{HEPES}, 40 \mathrm{mM}$ $\mathrm{NaOH}, 5.6 \mathrm{mM}$ glucose, $1 \mathrm{mM} \mathrm{CaCl}_{2}$, 0.1\% BSA, $\mathrm{pH}$ 7.2)와 시료 각각 $0,100,200,400,800 \mu \mathrm{g} / \mathrm{mL}$ 를 순차적으로 10 분간 전 처리한 후 $1 \mu \mathrm{g} / \mathrm{mL}$ 의 DNP-bovine serum albumin (DNP-BSA)과 1시간 배양하여 세포를 활성화시켰다. 배양이 끝난 후 원심 분리 $\left(12,000 \mathrm{rpm}, 10\right.$ 분, $\left.4^{\circ} \mathrm{C}\right)$ 를 통해 분리한 상층 액 $25 \mu \mathrm{L}$ 를 $1 \mathrm{mM}$ 기질용액(p-nitrophenyl- $\beta$-acetyl-glucosamide in citrate buffer $0.1 \mathrm{M}, \mathrm{pH}$ 4.5) $50 \mu \mathrm{L}$ 와 $37^{\circ} \mathrm{C}$ 에서 1 시간 반응 시켰다. 반응 후 stop solution $\left(0.1 \mathrm{M} \mathrm{Na}_{2} \mathrm{CO}_{3} /\right.$ $\mathrm{NaHCO}_{3}, \mathrm{pH}$ 10) $150 \mu \mathrm{L}$ 를 첨가하여 반응을 정지시켰으며, $405 \mathrm{~nm}$ 에서 흡광도를 측정하였다[19].

\section{8. 섬유아세포에 대한 세포독성 평가}

인간 유래의 섬유아세포인 CCD-986sk 세포는 한국세포주 은행(서울, 한국)에서 분양 받아 사용하였으며, 세포는 $10 \%$ FBS와 1\% antibiotics (penicillin/streptomycin)를 함유하는 $\mathrm{IMDM}$ 배지를 사용하여 $5 \% \mathrm{CO}_{2}, 37^{\circ} \mathrm{C}$ 조건에서 배양하였다. 세포독성을 평가하기 위해 세포를 $1 \times 10^{4}$ cells/well의 밀도로 48-well plate에 분주하고 24시간 배양 후, 각 농도별 편백나무 잎 추출물을 24 시간 처리하였다. 그 후 MTT 시약 $(2.5 \mathrm{mg} / \mathrm{mL})$ 을 각 well에 $25 \mu \mathrm{L}$ 씩 첨가하여 3 시간 배양한 다음, 상층액을 제
거하고 각 well에 생성된 formazan 결정을 $\mathrm{DMSO}$ 로 용해시켜 $550 \mathrm{~nm}$ 에서 흡광도를 측정하였다. 세포독성은 무처리군의 생 존율을 기준으로 각 처리군의 상대적인 세포생존율(cell viability)을 평가하여 계산하였다.

\section{9. 통계 처리}

모든 데이터는 최소 3 번 반복하여 평균과 표준오차 (mean $\pm \mathrm{SEM}$ )로 나타내었으며, 통계 분석에는 SPSS statistics 22 (Version 22.0, SPSS Inc., Chicago, IL, USA)가 사용되었다. 또한, 그룹 간의 유의성 차이 검증에는 일원배치 분산분석 (one-way ANOVA)을 사용하였으며, Duncan's multiple range test 방법을 통한 사후 검증을 시행하였다. 두 그룹 사이 의 비교에는 t-test를 사용하였으며, 유의확률이 $p$ 값이 0.05 미 만인 경우 통계적으로 유의한 것으로 판단하였다.

\section{결 과}

\section{GC-MS (Gas chromatography-mass spectrometry)를 이용한 편백나무 잎 추출물의 주요성분 함량 분석}

편백나무 잎 추출물의 주요성분에 대한 함량분석을 위한 검 량선은 상관계수(r)를 구하여 직선성을 판단하였으며, 6종 성분 에 대한 검량선 작성 결과 상관 계수(r) 값이 0.9997 이상으로 1.0 에 가까운 양호한 직선성을 나타내었다. 검액에서의 피크 확 인은 표준물질의 피크 머무름 시간을 비교하여 확인하였다. $\alpha$-Terpinene, $\alpha$-Terpineol, limonene, borneol, myrcene 및 sabinene 6종의 성분은 5.22분, 5.37분, 8.36분, 10.39분, 10.81 분 및 12.34 분에 각각 검출되었다(Figure 1). 설정된 $\mathrm{GC}-\mathrm{MS}$ 분석법으로 편백나무 잎 추출물의 6종 성분에 대한 함 량 분석을 실시한 결과, $\alpha$-Terpinene $3.03 \mathrm{mg} / \mathrm{g}, \alpha$-Terpineol $9.48 \mathrm{mg} / \mathrm{g}$, limonene $5.96 \mathrm{mg} / \mathrm{g}$, borneol $59.78 \mathrm{mg} / \mathrm{g}$, myrcene $4.85 \mathrm{mg} / \mathrm{g}$, sabinene $11.31 \mathrm{mg} / \mathrm{g}$ 로 나타났다 (Table 1).

\section{2. 총 폴리페놀 함량}

편백나무 잎 추출물의 총 폴리페놀의 함량을 gallic acid를 기 준물질로 하여 측정하였다(Table 2). Gallic acid로 환산한 편백 나무 잎 추출물의 총 폴리페놀 함량은 $25.89 \pm 0.31 \mathrm{mg} \mathrm{GAE} / \mathrm{g}$ 로 범위로 나타났다. 


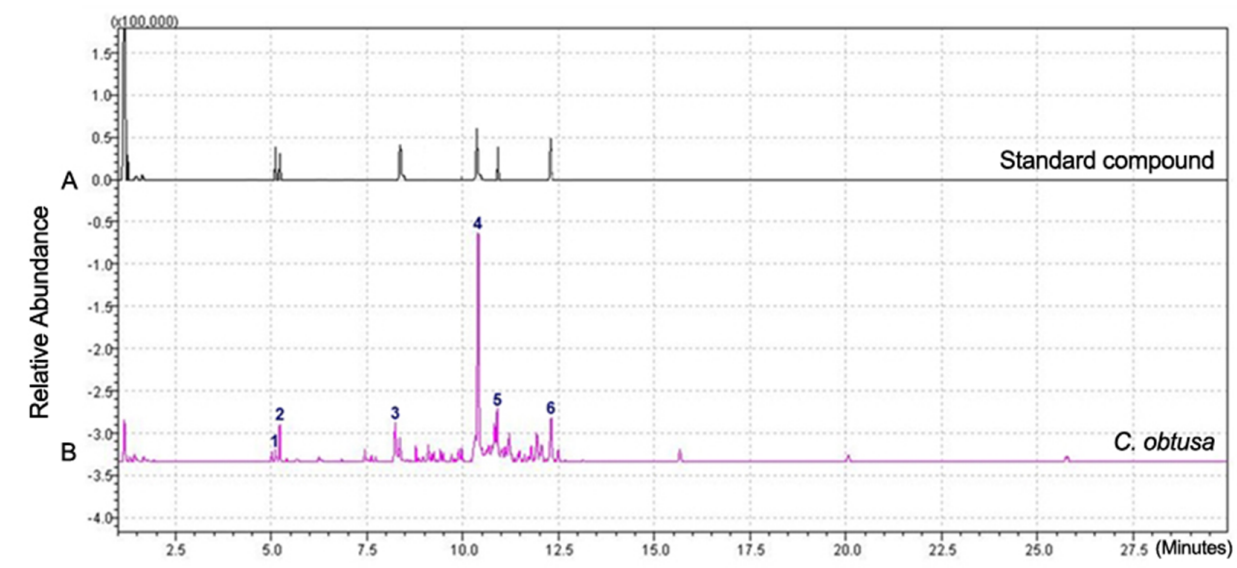

Figure 1. GC-MS condition of $C$. obtusa (CO) leaf extraction. (A) The pattern of standard compounds. (B) The pattern of CO (1. $\alpha$-Terpinene; 2. $\alpha$-Terpineol; 3. limonene; 4. borneol; 5. myrcene; 6. sabinene).

Table 1. Results of chemical composition analysis of $C$. obtusa leaf extract

\begin{tabular}{cccccccc}
\hline \multirow{2}{*}{ Components } & \multicolumn{5}{c}{ Analysis of contents $(\mathrm{mg} / \mathrm{g})$} \\
\cline { 2 - 7 } & $\alpha$-Terpinene & $\alpha$-Terpineol & Limonene & Borneol & Myrcene & Sabinene \\
\hline C. obtusa leaf extract & 3.03 & 9.48 & 5.96 & 59.78 & 4.85 & 11.31 \\
\hline
\end{tabular}

Table 2. Total polyphenol contents of $C$. obtusa leaf extract

\begin{tabular}{cc}
\hline Sample & Total polyphenol contents \\
\hline C. obtusa leaf extract & $25.89 \pm 0.31 \mathrm{mg} \mathrm{GAE} / \mathrm{g}$ \\
\hline
\end{tabular}

${ }^{*}$ Gallic acid equivalent.

\section{3. 인간 유래의 섬유아세포인 CCD-986sk 세포에 대한 편백나무 잎 추출물의 세포독성}

CCD-986sk 세포에 편백나무 잎 추출물을 24시간 처리하여 세포생존율을 확인한 결과, 편백나무 잎 추출물(100 800 $\mu \mathrm{g} / \mathrm{mL}$ )은 CCD-986sk 세포에 대해 유의적인 세포독성을 나타 내지 않았다(Figure 2).

\section{Hydrogen peroxide $\left(\mathrm{H}_{2} \mathrm{O}_{2}\right)$ 소거 활성 측정}

편백나무 잎 추출물의 $\mathrm{H}_{2} \mathrm{O}_{2}$ 에 대한 저해활성은 $\mathrm{RC}_{50}$ 와 trolox의 활성과 비교하여 trolox 당량값(trolox equivalent antioxidant capacity, TEAC)으로 나타내었다. 그 결과 편백나 무 잎 추출물의 $\mathrm{RC}_{50}$ 과 $\mathrm{TEAC}$ 는 각각 $5.47 \pm 0.13 \mathrm{mg} / \mathrm{mL}$ 과 $1.35 \pm 0.11 \mathrm{mg} \mathrm{TE} / \mathrm{g}$ 로 나타났다(Table 3 ).

\section{ABTS radical cation 소거작용 측정 2,2'-Azino-bis} (3-ethylbenzothiazoline-6-sulfonic acid (ABTS)) 라디칼 소거 활성

편백나무 잎 추출물의 ABTS radical cation 소거활성은

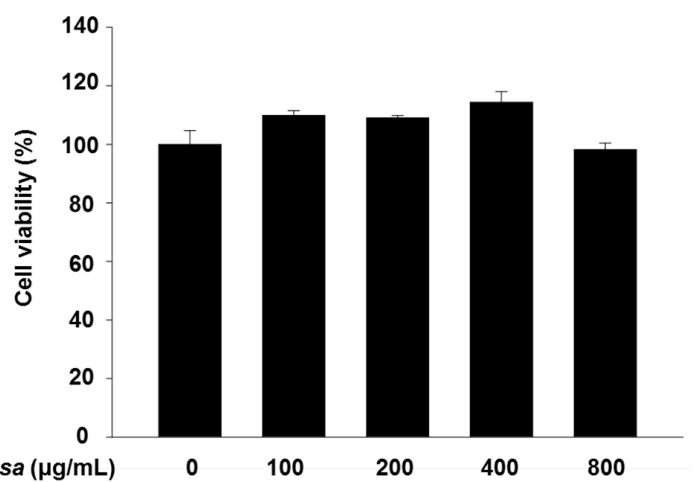

C. obtusa $(\mu \mathrm{g} / \mathrm{mL})$

Figure 2. Viability of C. Obtusa leaf extracts in CCD-986sk cells. Cell viability was measured by MTT assay. Abbreviation: CO, Chamaecyparis obtusa.

$\mathrm{RC}_{50}$ 와 trolox의 활성과 비교하여 trolox 당량값으로 나타내었 다. 그 결과 편백나무 잎 추출물의 $\mathrm{RC}_{50}$ 과 $\mathrm{TEAC}$ 는 각각 $4.00 \pm 0.01 \mathrm{mg} / \mathrm{mL}$ 과 $5.21 \pm 0.05 \mathrm{mg}$ TE/g로 나타났다(Table 4).

\section{6. 편백나무 잎 추출물에 의해 RAW 264.7 세포에서 LPS로 유도된 Nitric Oxide (NO)의 저해}

RAW 264.7 세포에 LPS $100 \mathrm{ng} / \mathrm{mL}$ 을 처리한 군에서 $\mathrm{NO}$ 생 성이 $28 \pm 0.38 \mu \mathrm{M}$ 까지 증가하였으나 편백나무 잎 추출물 100 $\mu \mathrm{g} / \mathrm{mL}$ 처리 군에서 $\mathrm{NO}$ 생성은 $18.34 \pm 0.67 \mu \mathrm{M}$, 편백나무 잎 추출물 $200 \mu \mathrm{g} / \mathrm{mL}$ 처리 군에서 $\mathrm{NO}$ 생성은 $11.45 \pm 0.57 \mu \mathrm{M}$ 로 농도 의존적, 유의적으로 감소하였다(Figure 3A). 한편 LPS 를 처리한 RAW 264.7 세포의 경우 무처리군 대비 약 $60 \%$ 정도 


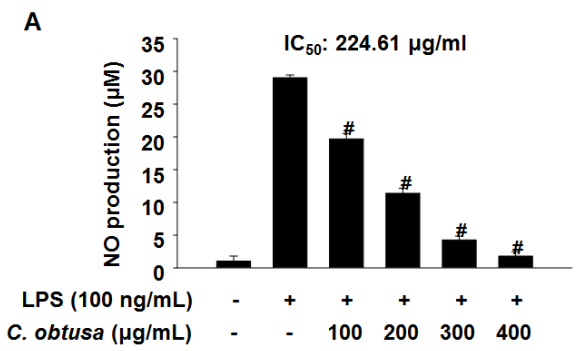

B

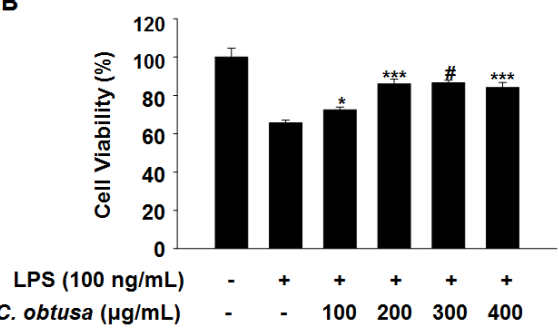

Figure 3. Effects of $\mathrm{CO}$ on $\mathrm{NO}$ production and cell viability in LPS-treated Raw 264.7 cells. Raw 264.7 cells were treated with indicated concentration of $C$. obtusa leaf extract and LPS $(100 \mathrm{ng} / \mathrm{mL})$ for $24 \mathrm{~h}$. Results were presented as mean $\pm \mathrm{SE}$ of three independent experiments. ${ }^{\star} p<0.05$, ${ }^{\star * \star} p<0.005,{ }^{*} p<0.001$ vs LPS control. Abbreviation: CO, Chamaecyparis obtusa.
Table 3. Scavenging effects of trolox and C. obtusa leaf extract on hydrogen peroxide

\begin{tabular}{lcc}
\hline \multicolumn{1}{c}{ Sample } & $\mathrm{RC}_{50}{ }^{*}$ & $\mathrm{TEAC}(\mathrm{mg} \mathrm{TE} / \mathrm{g})^{\star *}$ \\
\hline C. obtusa leaf extract & $5.47 \pm 0.13 \mathrm{mg} / \mathrm{mL}$ & $1.35 \pm 0.11$ \\
Trolox & $4.86 \pm 0.13 \mu \mathrm{g} / \mathrm{mL}$ & - \\
\hline
\end{tabular}

${ }^{*}$ Concentration required for $50 \%$ reduction of $\mathrm{ABTS}^{+} \cdot$ at $10 \mathrm{~min}$ after starting the reaction.

**Trolox equivalent antioxidant capacity.

Table 4. Scavenging effects of trolox and C. obtusa leaf extract on 2,2'-azino-bis (3-ethylbenzthiazoline-6-sulfonic acid) radical $\left(\mathrm{ABTS}^{+}\right)$

\begin{tabular}{lcc}
\hline \multicolumn{1}{c}{ Sample } & $\mathrm{RC}_{50}{ }^{*}$ & $\mathrm{TEAC}(\mathrm{mg} \mathrm{TE} / \mathrm{g})^{\star \star}$ \\
\hline C. obtusa leaf extract & $4.00 \pm 0.01 \mathrm{mg} / \mathrm{mL}$ & $5.21 \pm 0.05$ \\
Trolox & $11.80 \pm 0.12 \mu \mathrm{g} / \mathrm{mL}$ & -
\end{tabular}

${ }^{*}$ Concentration required for $50 \%$ reduction of $\mathrm{ABTS}^{+} \cdot$ at $1 \mathrm{~min}$ after starting the reaction.

**Trolox equivalent antioxidant capacity.

의 세포생존율을 보였으나, 추출물을 함께 처리한 세포의 경우 생포생존율이 유의적인 증가를 보였다(Figure 3B).

\section{7. 편백나무 잎 추출물이 IgE에 감작된 $\mathrm{RBL}-2 \mathrm{H} 3$ 세포에서 항 알레르기 효과}

편백나무 잎 추출물의 항 알레르기 작용을 보기위해 자극된 DNP-specific IgE에 대한 $\beta$-hexosaminidase는 편백나무 잎 추출물의 농도 의존적으로 감소되었다(Figure 4).

\section{고 찰}

본 연구는 전라도 장성지역의 편백나무 잎 추출물을 사용하 여 in vitro에서 항염증 및 항알레르기 효과를 보고자 연구를 진 행하였다. Lee 등[20]의 선행연구에서는 에틸아세테이트 분획 을 당 제거한 아글리콘 분획의 HPLC 정량분석 결과 quercetin 성분이 $83.9 \%$, taxifolin $9.26 \%$, kaempferol 6.77\%로 나타났 으나 총 폴리페놀함량에 관한 결과는 없었다. 본 연구에서는 편

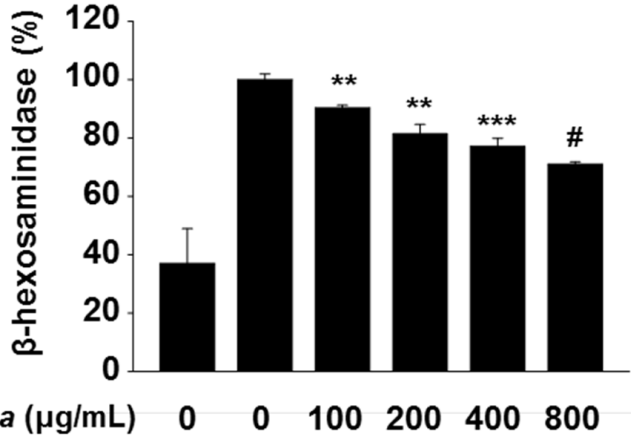

DNP-BSA

Figure 4. Effect of $\mathrm{CO}$ on degranulation in IgE-mediated RBL-2H3 cells. RBL-2H3 cells were incubated with $1 \mu \mathrm{g} / \mathrm{mL}$ of DNP-specific $\operatorname{IgE}$ for $18 \mathrm{~h}$. The IgE sensitized cells were preincubated with CO $(0-800 \mu \mathrm{g} / \mathrm{mL})$ for $10 \mathrm{~min}$ and then stimulated with $1 \mu \mathrm{g} / \mathrm{mL}$ of DNP-BSA for $1 \mathrm{~h}$. The degranulation was determined by measurement of the activity of $\beta$-hexosaminidase in culture media. The value represents mean $\pm \mathrm{SE}$ of three different experiments. ${ }^{* *} p<0.01$, ${ }^{\star * \star} p<0.005,{ }^{\#} p<0.001$ vs. DNP-BSA treated group. Abbreviation: $\mathrm{CO}$, Chamaecyparis obtusa.

백나무 잎을 열수 추출한 편백나무 잎 추출물의 폴리페놀 함량 농도를 높이기 위해 $50^{\circ} \mathrm{C}$ 에서 감압 건조하여 실험에 사용한 결 과 총 폴리페놀 함량이 $25.89 \pm 0.31 \mathrm{mg} \mathrm{GAE} / \mathrm{g}$ 로 나타났다. 추 출용매에 따른 총 폴리페놀 함량에 관한 비교 자료가 미비하여, 편백나무의 지역별, 부위별 연구가 더 필요할 것으로 사료된다. 본 연구에서는 $\alpha$-Terpinene 보다 졸음방지에 생리활성이 있는 borneol 성분이 가장 많았다. 이는 추출방법에 따라 유효 지표 성분이 다르게 나타난다는 결과를 시사한다.

$\mathrm{H}_{2} \mathrm{O}_{2}$ 저해활성 측정은 항산화제가 $\mathrm{H}_{2} \mathrm{O}_{2}$ 와 같은 proxidants 의 함량을 감소시키는 능력을 측정하는 가장 유용한 방법 중의 하나이다. $\mathrm{H}_{2} \mathrm{O}_{2}$ 는 약한 산화제로 효소의 필수기인 thiol group 을 산화시켜 일부 효소의 활성을 직접적으로 감소시키는 것으 로 알려져 있다. 또한 $\mathrm{H}_{2} \mathrm{O}_{2}$ 는 반응성이 있는 non-radical 물질 로 생체막을 직접적으로 통과할 수 있기 때문에 매우 중요하다. $\mathrm{H}_{2} \mathrm{O}_{2}$ 는 생체막을 통과하면 다양한 반응을 통해서 반응성이 큰 singlet oxygen 및 hydroxyl radical 로 전환되어 지질과산화 
또는 세포내에서 독성을 유발시킨다[17]. 본 연구에서는 $\mathrm{H}_{2} \mathrm{O}_{2}$ 에 대한 편백나무 잎 추출물의 $\mathrm{RC}_{50}$ 과 $\mathrm{TEAC}$ 는 각각 $5.47 \pm 0.13$ $\mathrm{mg} / \mathrm{mL}$ 과 $1.35 \pm 0.11 \mathrm{mg} \mathrm{TE} / \mathrm{g}$ 로 나타났다. ABTS radical cation 소거활성은 2,2'-azino-bis (3-ethylbenzothiazoline6-sulfonic acid) diammonium salt (ABTS)와 potassium persulfate와의 반응으로 $\mathrm{ABTS}^{+}$radical이 생성되면 특유의 색 인 청록색을 띄게 되는데, 시료를 첨가함에 따라 연한녹색으로 decolorization되는 것을 측정하는 방법으로 hydrogen donating antioxidant와 chain breaking antioxidant 모두를 측정 할 수 있는 방식을 이용하였다[16]. 연구 결과 편백나무 잎 추출물의 $\mathrm{RC}_{50}$ 과 $\mathrm{TEAC}$ 는 각각 $4.00 \pm 0.01 \mathrm{mg} / \mathrm{mL}$ 과 $5.21 \pm 0.05 \mathrm{mg}$ $\mathrm{TE} / \mathrm{g}$ 로 나타났다. Kodikonda와 Prakash [21]는 monoterpene borneol이 항산화효과가 있다고 보고한 바와같이 본 연구에서 사용된 장성유래 편백나무 잎 추출물 분석결과에서도 효과가 일치하여 borneol 이 주된 역할을 할 것으로 생각되며 연구자들 이 추구하는 피부적용에는 항산화 효과를 나타낼 것으로 보인다. 편백추출 에센셜 오일이 rat에서 COX-2 통로를 통해 항염증 효과를 보고하였고[5], 편백정유가 항균, 항염, 항산화 효과가 있다고 보고하였다[22]. 본 연구에서는 마우스 유래의 대식세 포주인 RAW 264.7 세포에서 LPS $100 \mathrm{ng} / \mathrm{mL}$ 을 처리한 군에서 $\mathrm{NO}$ 생성이 $28 \pm 0.38 \mu \mathrm{M}$ 까지 증가하여 편백나무 잎 추출물 $150 \mu \mathrm{g} / \mathrm{mL}$ 의 농도에서 처리에서 $\mathrm{IC}_{50}$ 으로 감소할 것으로 추정 된다. 따라서 본 연구결과는 편백나무 잎 추출물이 항염증 작용 이 있음을 시사한다. Kim 등[23]의 선행 연구에서 따르면 기도 에 염증을 유발한 Murine 천식모델에서 편백나무 잎에서 추출 한 에센셜오일이 과민반응을 감소시킨다고 보고되었다. Lee 등 [20]의 연구에서도 생달나무(Cinnamomum japonicum) 등 50 여 종의 식물의 잎, 뿌리, 줄기 등에서 추출물이 IgE로 조절된 $\mathrm{RBL}-2 \mathrm{H} 3$ 세포에서의 탈 과립 억제 활성을 보고하였다. 그러나 편백나무 잎 추출물에서 항알레르기 효과를 보기위한 연구는 보고된 바 없었다. 편백나무 잎 추출물의 항알레르기 작용을 보 기위해 자극된 DNP-specific IgE에 대한 $\beta$-hexosaminidase 의 방출은 탈 과립지수를 나타낸다. 본 연구결과 $\beta$-hexosaminidase는 편백나무 잎 추출물의 농도 의존적으로 감소되어 항알레르기 효능이 있음을 알 수 있었으며, RBL-2H3세포에 대 한 세포독성 실험결과 5 시간까지는 독성이 없는 것으로 나타났 다(data not shown).

Kang 등[24]에 의하면 피톤치드가 MAC-T 세포에 대한 세포 독성 실험결과 $0.08 \%$ 의 농도에서 $20 \%$ 세포생존율을 보고한 바 있다. 본 연구결과 CCD-986sk 세포에서 편백나무 잎 추출물의 농도 $800 \mu \mathrm{g} / \mathrm{mL}$ 농도에서 세포 생존율이 감소되지 않았다. 이
결과에서 편백나무 잎 추출물은 세포독성이 나타나지 않는다는 것을 알 수 있다. 따라서, 편백나무 잎 추출물은 향 후 기능성 화 장품, 연고 등의 산업화에 광범위하게 이용될 수 있을 것으로 사 료된다.

\section{요 약}

본 연구는 전라도 장성지역의 편백나무 잎 추출물을 사용하 여 in vitro에서 항염증 및 항알레르기 효과를 보고자 연구를 진 행하였다. 편백나무 잎 추출물은 $50^{\circ} \mathrm{C}$ 에서 감압 건조하여 실험 에 사용하였으며, 총 폴리페놀 함량을 측정한 결과 $25.89 \pm 0.31$ $\mathrm{mg} \mathrm{GAE} / \mathrm{g}$ 로 나타났다. 설정된 GC-MS 분석법으로 편백나무 잎 추출물의 6종 성분에 대한 함량 분석을 실시한 결과, $\alpha$-Terpinene $3.03 \mathrm{mg} / \mathrm{g}$, $\alpha$-Terpineol $9.48 \mathrm{mg} / \mathrm{g}$, limonene 5.96 mg/g, borneol $59.78 \mathrm{mg} / \mathrm{g}$, myrcene $4.85 \mathrm{mg} / \mathrm{g}$, sabinene $11.31 \mathrm{mg} / \mathrm{g}$ 로 borneol이 가장 많은 것으로 나타났다. 편백나 무 잎 추출물의 항산화 활성을 측정한 결과, $\mathrm{H}_{2} \mathrm{O}_{2}$ 와 $\mathrm{ABTS}^{+}$라 디칼에 대한 추출물의 $\mathrm{RC}_{50}$ 이 각각 $5.47 \pm 0.13 \mathrm{mg} / \mathrm{mL}$ 와 $4.00 \pm 0.01 \mathrm{mg} / \mathrm{mL}$ 로 나타났다. 또한 마우스 유래의 대식세포 주인 RAW 264.7 세포에서 LPS $100 \mathrm{ng} / \mathrm{mL}$ 을 처리를 통한 염증 유도 군에서 주요 인자인 $\mathrm{NO}$ 생성이 $28 \pm 0.38 \mu \mathrm{M}$ 까지 증가하 였으나 편백나무 잎 추출물 $150 \mu \mathrm{g} / \mathrm{mL}$ 처리 농도에서 $\mathrm{IC}_{50}$ 으 로 감소할 것으로 추정되므로, 편백나무 잎 추출물이 항염증 작 용이 있음을 시사한다. 알레르기 주요 인자인 $\beta$-hexosaminidase 의 경우 처리한 편백나무 잎 추출물의 농도 의존적으로 감소되 어 항알레르기 효능이 있음을 알 수 있었으며, 인간 유래 섬유아 세포인 CCD-986sk 세포에 대해 편백나무 잎 추출물의 농도 $100 \sim 800 \mu \mathrm{g} / \mathrm{mL}$ 범위에서 세포독성을 전혀 보이지 않았다. 따라서 편백나무 잎 추출물이 향후 기능성 화장품, 연고 등의 산 업화에 광범위하게 이용될 수 있을 것으로 사료된다.

Acknowledgements: This research was supported by Ministry of Trade, Industry and Energy of Korea funded by development of core technologies in the region (No. R0005839).

Funding: None

Conflict of interest: None

\section{REFERENCES}

1. Yang JK, Choi MS, Seo WT, Rinker DL, Han SW, Cheong GW. 
Chemical composition and antimicrobial activity of Chamaecyparis obtuse leaf essential oil. Fitoterapia. 2007;78(2):149-152.

2. Lee JH, Lee BK, Kim JH, Lee SH, Hong SK. Comparison of chemical compositions and antimicrobial activities of essential oils from three conifer trees; Pinus densiflora, Cryptomeria japonica, and Chamaecyparis obtusa. J Microbiol Biotechnol. 2009;19(4):391-396.

3. Jang YS, Lee CH, Kim MK, Kim JH, Lee SH, Lee HS. Acaricidal activity of active constituent isolated in Chamaecyparis obtusa leaves against Dermatophagoides spp. J Agric Food Chem. 2005;53(6):1934-1937.

4. An BS, Kang JH, Yang H, Jung EM, Kang HS, Choi IG, et al. Anti-inflammatory effects of essential oils from Chamaecyparis obtusa via the cyclooxygenase-2 pathway in rats. Molecular medicine reports. 2013;8(1):255-259.

5. Jeong EJ, Hwang L, Lee M, Lee KY, Ahn MJ, Sung SH. Neuroprotective biflavonoids of Chamaecyparis obtusa leaves against glutamate-induced oxidative stress in HT22 hippocampal cells. Food Chem Toxicol. 2014;64:397-402.

6. Park HJ, Kim SK, Kang WS, Woo JM, Kim JW. Effects of essential oil from Chamaecyparis obtusa on cytokine genes in the hippocampus of maternal separation rats. Can J Physiol Pharmacol. 2013;92(2):95-101.

7. Tang B, Lee YJ, Lee YR, Row KH. Examination of 1-methylimidazole series ionic liquids in the extraction of flavonoids from Chamaecyparis obtuse leaves using a response surface methodology. J Chromatogr B Analyt Technol Biomed Life Sci. 2013;933(15):8-41.

8. Inaba H, Nagaoka Y, Kushima Y, Kumagai A, Matsumoto Y, Sakaguchi M, et al. Comparative examination of anti-proliferative activities of (-)-epigallocatechin gallate and (--)-epigallocatechin against HCT116 colorectal carcinoma cells. Biol Pharm Bull. 2008;31(1):79-84.

9. Bose B, Choudhury H, Tandon P, Kumaria S. Studies on secondary metabolite profiling, anti-inflammatory potential, in vitro photoprotective and skin-aging related enzyme inhibitory activities of Malaxis acuminata, a threatened orchid of nutraceutical importance. J Photochem Photobiol B. 2017; 173(10):686-695.

10. Haratake A, Uchida Y, Schmuth M, Tanno O, Yasuda R, Epstein $\mathrm{JH}$, et al. UVB-induced alterations in permeability barrier function: roles for epidermal hyperproliferation and thymocytemediated response. J Invest Dermatol. 1997;108(5): 769-775.

11. Kim MY, Cho DO, Back OH, Lee BH. Effects of body composition, nutrient intakes and biochemical indices on skin health status of female university students with sensitive skin. Korean J
Food Culture. 2008;23(2):258-267.

12. Yang YM, Kang SM. The effects of the application of ceramide emulsion on the improvement of skin makeup in sensitive skin women in their 20`s. J Kor Soc Cosm. 2013; 19(5):891-901.

13. Imokawa G, Abe A, Jin K, Higaki A. Decreased level of ceramides in straum corneum dr atopic dermatitis: an etologic facter on atopic dry skin. J Invest Dermtol. 1991;96(4):523-526.

14. Chen YJ, Lin CY, Cheng SS, Chang ST. Phylogenetic relationships of the genus Chamaecyparis inferred from leaf essential oil. Chem Biodivers. 2011;8(6):1083-1097.

15. Singleton VL. Naturally occurring food toxicants: phenolic substances of plant origin common in foods. Advances Food Res. 1981;27(21):149-242.

16. Re R, Pellegrini N, Proteggente A, Pannala A, Yang M, Rice-Evans C. Antioxidant activity applying an improved ABTS radical cation decolorization assay. Free Radic Biol Med. 1999; 26(9-10):1231-1237.

17. Lee SO, Lee HJ, Yu MH, Im HG, Lee IS. Total polyphenol contents and antioxidant activities of methanol extracts from vegetables produced in ullung island. Korean J Food Sci Technol. 2005;37(2):233-240.

18. Green LC, Wagner DA, Glogowski J. Analysis of nitrate, nitrite, and $\left[15^{\mathrm{N}}\right]$ nitrate in biological fluids. Anal Biochem. 1982; 126(1):131-138.

19. Lee SE, Joung HG, Lee DY, Lee JH, Choi J, Kim GS, et al. Inhibition activity of plants on IgE-mediated degranulation of RBL-2H3 cells. Korean J Plant Resources. 2015;28(12):718-726.

20. Lee DS, Lim MS, Kwan SS, Kim SY, Park SN. Antioxidative activity and componential analysis of Chamaecyparis obtusa leaf extract. App Chem Eng. 2012;23(1):93-99.

21. Kodikonda M, Prakash RN. Ameliorative effect of borneol, a natural bicyclic monoterpene against hyperglycemia, hyperlipidemia and oxidative stress in streptozotocin-induced diabetic Wistar rats. Biomed Pharmacother. 2017;96:336-347.

22. Ahn JY, Lee SS, Kang HY. Biological activities of essential oil from Chamaecyparis obtusa. J Soc Cosmet Scientists Korea. 2004; 30(4):503-507.

23. Kim SK, Lee SM, Lim HB. Attenuation effect of Chamaecyparis obtusa leaf essential oils on airway hyperresponsiveness and airway inflammation in ovalbumin-Induced murine asthma model. J Medicinal Crop Science. 2015;23(3):237-244.

24. Kang S, Lee JS, Lee HC, Petriello MC, Kim BY, Do JT, et al. Phytoncide extracted from pinecone decreases LPS-Induced inflammatory responses in bovine mammary epithelial cells. J Microbiol Biotechnol. 2016;26(3):579-587. 